\section{OPEN ACCESS}

Edited by:

Fabienne Langlois,

Centre Hospitalier Universitaire de

Sherbrooke, Canada

Reviewed by:

Aart J. Van Der Lely,

Erasmus University Rotterdam,

Netherlands

Laurence Katznelson,

Stanford University, United States

${ }^{*}$ Correspondence:

Marek Bolanowski

marek.bolanowski@umed.wroc.p

Zaina Adnan

zaina_adnan@yahoo.com

Specialty section:

This article was submitted to

Pituitary Endocrinology,

a section of the journal

Frontiers in Endocrinology

Received: 17 November 2021

Accepted: 19 January 2022

Published: 22 February 2022

Citation:

Bolanowski M, Adnan Z, Doknic M,

Guk M, Hána V, Ilovayskaya I,

Kastelan D, Kocjan T, Kužma M,

Nurbekova A, Poiana C, Szücs N,

Vandeva S, Gomez R, Paidac S,

Simoneau D and Shimon I (2022)

Acromegaly: Clinical Care in

Central and Eastern Europe,

Israel, and Kazakhstan.

Front. Endocrinol. 13:816426. doi: 10.3389/fendo.2022.816426

\title{
Acromegaly: Clinical Care in Central and Eastern Europe, Israel, and Kazakhstan
}

\begin{abstract}
Marek Bolanowski ${ }^{1 *}$, Zaina Adnan ${ }^{2 *}$, Mirjana Doknic ${ }^{3}$, Mykola Guk ${ }^{4}$, Václav Hána ${ }^{5}$, Irena llovayskaya ${ }^{6}$, Darko Kastelan ${ }^{7}$, Tomaz Kocjan $^{8,9}$, Martin Kužma ${ }^{10}$, Akmaral Nurbekova ${ }^{11}$, Catalina Poiana ${ }^{12}$, Nikolette Szücs ${ }^{13}$, Silvia Vandeva ${ }^{14}$, Roy Gomez ${ }^{15}$, Sorin Paidac ${ }^{16}$, Damien Simoneau ${ }^{17}$ and Ilan Shimon ${ }^{18}$

${ }^{1}$ Department of Endocrinology, Diabetes and Isotope Therapy, Wroclaw Medical University, Wroclaw, Poland, ${ }^{2}$ Division of Endocrinology and Metabolism, Bar Ilan Faculty of Medicine, Clalit Medical Health Care Services, Safed, Israel,

${ }^{3}$ Neuroendocrinology Department, Clinic for Endocrinology, Diabetes and Metabolic Diseases, Clinical Centre of Serbia, Medical Faculty University of Belgrade, Belgrade, Serbia, ${ }^{4}$ Department of Transsphenoidal Surgery, Romodanov Neurosurgery Institute, Kyiv, Ukraine, ${ }^{5}$ Third Department of Internal Medicine, First Faculty of Medicine, Charles University and General University Hospital, Prague, Czechia, ${ }^{6}$ Neuroendocrine Unit, Endocrinology Department, Moscow Regional Research and Clinical Institute, Moscow, Russia, ${ }^{7}$ Department of Endocrinology, University Hospital Center Zagreb, Zagreb, Croatia, ${ }^{8}$ Department of Endocrinology, Diabetes and Metabolic Diseases, University Medical Centre Ljubljana, Ljubljana, Slovenia, ${ }^{9}$ Faculty of Medicine, University of Ljubljana, Ljubljana, Slovenia, ${ }^{10}$ Comenius University Faculty of Medicine, 5th Department of Internal Medicine, University Hospital Bratislava, Bratislava, Slovakia, ${ }^{11}$ Kazakh National Medical University, Almaty, Kazakhstan, ${ }^{12}$ Department of Endocrinology, "Carol Davila" University of Medicine and Pharmacy, Bucharest, Romania, ${ }^{13}$ Department of Internal Medicine and Oncology, Semmelweis University, Budapest, Hungary, ${ }^{14}$ Department of Endocrinology, Specialized Hospital for Active Treatment of Endocrinology, Medical University, Sofia, Bulgaria, ${ }^{15}$ Global Medical Affairs, Pfizer Rare Disease, Brussels, Belgium, ${ }^{16}$ Medical Affairs, Pfizer Rare Disease, Bucharest, Romania, ${ }_{17}$ Central and Eastern Europe Medical Affairs, Pfizer Rare Disease, Paris, France, ${ }^{18}$ Rabin Medical Center, Petah-Tikva, and Sackler Faculty of Medicine, Tel-Aviv University, Tel-Aviv, Israel
\end{abstract}

Acromegaly is a rare condition typically caused by benign pituitary adenomas, resulting in excessive production of growth hormone. Clinical manifestations of acromegaly are diverse, varying from the overgrowth of body tissue to cardiovascular, metabolic, and osteoarticular disorders. Symptoms may emerge slowly, overlapping with other diseases and often involve many different healthcare specialists. In the last decade, efforts to provide an accurate and timely diagnosis of acromegaly have improved disease management and clinical experience. Despite this progress, marked differences in the diagnosis, treatment, and management of acromegaly exist from country-to-country. To address these inconsistencies in the region comprising Central and Eastern Europe, Israel, and Kazakhstan, a panel of acromegaly experts from 13 of these countries was convened. Acromegaly experts from each country provided available information on the approaches from their country, including regional treatment centers and multidisciplinary teams, treatment access, reimbursement and availability, and physician education, disease awareness, and patient advocacy. Across several areas of acromegaly management, divergent approaches were identified and discussed, including the provision of multidisciplinary care, approved and available treatments, and disease awareness programs. These were recognized as areas of potential improvement in the 
management of acromegaly, in addition to participation in national and regional acromegaly registries. Further experience exchange will facilitate the identification of specific strategies that can be adapted in each country, and widespread participation in acromegaly registries will enable their evaluation. It is anticipated that this approach will support the optimization of acromegaly patient care across this region.

Keywords: acromegaly, IGF-I, referral pathway, endocrinology, multidisciplinary care

\section{INTRODUCTION}

Acromegaly is a rare disease characterized by excess growth hormone $(\mathrm{GH})$ secretion, which promotes the increased synthesis of insulin-like growth factor-I (IGF-I). Benign pituitary adenomas represent the leading cause of acromegaly, and in $\sim 75 \%$ of cases, the excess GH production is driven by a pituitary macroadenoma (1). Clinical manifestations range broadly and may be related to the adenoma tumor mass itself, such as headache and visual impairment; or may be due to downstream effects of GH and IGF-I excess, for example, acral manifestations, respiratory disorders (such as snoring and sleep apnea), cardiovascular-related diseases, metabolic disorders (such as diabetes), and musculoskeletal disorders including osteoporosis, vertebral fractures and arthropathy (2). The increased mortality observed in patients with uncontrolled disease may be related in part to these disease-related comorbidities (3). A recently published large study involving 3173 patients with acromegaly from 10 European countries, including Bulgaria and the Czech Republic, reported that symptoms typically appear when patients are in their midthirties (median age: 33.5 years) (4). According to pooled data from 19 national acromegaly registries the mean age at diagnosis is about 45 years with an equal male to female ratio $(1,4)$.

\section{ACROMEGALY IN CENTRAL AND EASTERN EUROPE, ISRAEL \& KAZAKHSTAN}

Taking into consideration the disease rarity, it is not uncommon for endocrinologists - even those in specialist pituitary centers - to have relatively small numbers (dozens) of acromegalic patients under their supervision (4). Therefore, expert meetings represent a valuable platform for exchanging experience and improving clinical assessment and management.

To promote the exchange of clinical experience and best practice within and across the Central and Eastern European region (CEE), Israel, and Kazakhstan, a panel of 14 experts (13 endocrinologists and one neurosurgeon) from the region was convened to exchange insights on the diagnosis, treatment and follow-up of acromegaly. The following countries were represented: Bulgaria, Croatia, the Czech Republic, Hungary, Israel, Kazakhstan, Poland, Romania, Russia, Serbia, Slovakia, Slovenia, and Ukraine. Experts attended an advisory board held in Bratislava, Slovakia, on 16 October 2019 to initiate long-term discussions that led to this review. The acromegaly experts from each country provided general and holistic information on the approaches from their country, details on the regional treatment center(s) and multidisciplinary team, access, reimbursement, and availability to approved treatments, as well as physician education, disease awareness, and patient advocacy. During discussions, the topics covered included disease prevalence and treatment patterns, current clinical challenges, and potential ways to optimize patient care across this region in the future (Table 1).

Data from specialist centers in the region were used to estimate prevalence rates, ranging from 23 to 130 cases per million inhabitants (Table 1). This low prevalence with large-ranging differences within and between countries of the region may reflect the absence of official or mandatory national registries that are needed to produce reliable and freely available epidemiological data. Notably, the prevalence estimates shown in Table $\mathbf{1}$ are typically based on the number of patients treated in specialist centers that may not cover the entire population of a given country or region. Therefore, the panel concluded the importance of a national registry and the need for initiating this process.

\section{EARLY DIAGNOSIS AND COMPREHENSIVE APPROACH}

Owing to its diverse clinical presentation and the slow progression of symptoms that often overlap with those of other diseases, acromegaly is first suspected and eventually diagnosed by endocrinologists in the vast majority of cases $(2,4)$. After their initial primary care evaluation, patients with acromegaly often seek consultation in different disciplines for their symptoms, such as gynecologists for amenorrhea and fertility problems, ENT specialists for snoring, pulmonologists for obstructive sleep apnea, diabetologists for new-onset diabetes, and orthopedic surgeons for carpal tunnel syndrome. This time lag between the initial signs and symptoms and confirmed acromegaly diagnosis represents an important issue, and this varies somewhat by country across CEE, Israel, and Kazakhstan (Table 1). According to the pan-European database study, the median time from symptom onset to diagnosis was ten years in women and eight years in men $(2,4)$. It is noteworthy that this study showed a narrowing in the time gap between initial symptom presentation and diagnosis in recent years, which appears to be related to improved diagnostic modalities (4). Table 1 shows the estimated median time to acromegaly 
TABLE 1 | Estimated prevalence of acromegaly, the median time to diagnosis, and number of specialist centers, by country.

\begin{tabular}{|c|c|c|c|c|c|}
\hline $\begin{array}{l}\text { Country (approximate } \\
\text { total population*) }\end{array}$ & $\begin{array}{c}\text { Estimated prevalence, } \\
\text { per } 1,000,000 \\
\text { inhabitants }\end{array}$ & $\begin{array}{l}\text { Estimated current } \\
\text { total number of } \\
\text { patients diagnosed } \\
\text { with acromegaly }\end{array}$ & $\begin{array}{l}\text { Estimated median } \\
\text { time to diagnosis, } \\
\text { years }\end{array}$ & $\begin{array}{l}\text { Initial presentation to which } \\
\text { healthcare practitioners? }\end{array}$ & References \\
\hline Bulgaria (7.3 million) & 50 & 400 & 8 & $\begin{array}{l}\text { GPs, endocrinologists, gastroenterologists, } \\
\text { gynecologists, dentists }\end{array}$ & \\
\hline Croatia (4.4 million) & 85 & $\sim 300$ & $\begin{array}{l}7 \text { (range: 4-9) } \\
\text { Unpublished data } \\
\text { from CRO-aCRO } \\
\quad \text { Registry }\end{array}$ & $\begin{array}{l}\text { GPs, endocrinologists, neurosurgeons, } \\
\text { ophthalmologists, dentists }\end{array}$ & \\
\hline $\begin{array}{l}\text { Czech Republic ( } 10.5 \\
\text { million) }\end{array}$ & No data available & 600 & 4 & $\begin{array}{l}\text { GPs, endocrinologists, internal medicine } \\
\text { specialists, neurologists }\end{array}$ & \\
\hline Hungary (9.9 million) & $55-69$ & 450 & $3-9$ & $\begin{array}{l}\text { GPs, endocrinologists, neurosurgeons, } \\
\text { internal medicine specialists }\end{array}$ & \\
\hline Israel (9.3 million) & 80 & 700 & $4-6$ & $\begin{array}{l}\text { GPs, endocrinologists, neurosurgeons, } \\
\text { orthopedic surgeons }\end{array}$ & \\
\hline Kazakhstan (17.1 million) & $40-70$ & $\begin{array}{l}\text { Complete data not } \\
\text { available }\end{array}$ & $5-10$ & GPs, endocrinologists & \\
\hline Poland (38.1 million) & 70 & 2500 & 6 & $\begin{array}{l}\text { GPs, endocrinologists, internal medicine } \\
\text { specialists }\end{array}$ & \\
\hline Romania (21.4 million) & No data available & 1000 & $4-7$ & $\begin{array}{l}\text { GPs, endocrinologists, neurosurgeons, } \\
\text { rheumatologists, pneumologists }\end{array}$ & \\
\hline Russia (146.2 million) & 23-90; varies by region & 4300 & $6(2-25)$ & $\begin{array}{l}\text { GPs, endocrinologists, neurosurgeons, } \\
\text { gynecologists }\end{array}$ & (5) \\
\hline Serbia $^{\dagger}$ (6.9 million) & 60 & 400 & $5-7$ & $\begin{array}{l}\text { Neurosurgeons, neurologists, } \\
\text { endocrinologists, cardiologists, radiologists }\end{array}$ & \\
\hline Slovakia (5.4 million) & No data available & 350 & 5 & GPs, endocrinologists, neurologists & \\
\hline Slovenia (2.1 million) & 60 & 70 & $5-10$ & $\begin{array}{l}\text { GPs, endocrinologists, dentists, ear/nose/ } \\
\text { throat specialists, plastic surgeons, } \\
\text { neurosurgeons, pulmonologists, } \\
\text { gynecologists }\end{array}$ & \\
\hline Ukraine (45.1 million) ${ }^{\ddagger}$ & No data available & $\begin{array}{l}\text { Complete data not } \\
\text { available }\end{array}$ & 9 & Endocrinologists, neurosurgeons & $(6,7)$ \\
\hline
\end{tabular}

diagnosis, similar to previously reported data $(2,4)$; however, a wide range (3-10 years) was observed across CEE, Israel, and Kazakhstan.

During the panel discussion, it was reported that in Romania, Russia, and Ukraine, some patients with pituitary tumors might be presented directly to neurosurgery without hormonal evaluation or presurgical endocrinological consultation. The panel agreed unanimously that this approach is misleading and emphasized that pre- and post-operative endocrinological evaluation is mandatory. The experts recommended that endocrinologists work closely with neurosurgeons and participate in neurosurgical meetings to increase awareness of acromegaly and its management, encouraging referrals to surgeons at pituitary tumor centers of excellence.

Given the range of signs and symptoms associated with acromegaly, the expert panel concluded that a crucial step for reducing the time to diagnosis is to improve disease awareness and its cluster of signs and symptoms among nonendocrinologist healthcare practitioners.

Additionally, it is important to adopt scoring tools such as ACROSCORE and ACRO-POLIS that have been developed to aid physicians in earlier identification of the disease and further reduce the delay to diagnosis and treatment by taking into account multiple signs and symptoms associated with acromegaly, such as colorectal polyps, carpal tunnel syndrome, spaced teeth, and thyroid hyperplasia $(2,8)$. A recent study by Antsiferov et al. (2021) demonstrated the effectiveness of selective screening for improving diagnosis and more accurately assessing the prevalence of acromegaly. Unfortunately, such tools have not yet been widely adopted in the region (9). For example, in Bulgaria, Russia, Croatia, and Slovenia, ACROSCORE is not currently used; in many cases, translation into local languages and raising awareness amongst physicians who encounter cases are planned or in progress to encourage adoption into clinical practice. Similar approaches with other tools would likely be beneficial, and it is expected that the implementation of screening and scoring tools will facilitate the identification of likely cases of acromegaly by general practitioners and non-endocrinology specialists.

\section{COMORBIDITIES}

Acromegaly is a chronic disease associated with severe complications and comorbidities that may persist despite biochemical control of the disease $(10,11)$. The severity of these complications is correlated with diagnostic delay and the presence of active acromegaly (1). These include cardiovascular 
and metabolic complications $(5,12-15)$, in addition to respiratory, intestinal, and skeletal disorders and particular neoplasms (5, 14, 16-19), all of which can impair patients' quality of life and may contribute to increased mortality (10). Women of reproductive age may also experience menstrual cycle disorders that coincide with the initial onset of acromegaly symptoms (20). Data from Bulgaria and Poland showed that $95 \%$ of patients suffered from comorbidities, with other endocrine and metabolic diseases and cardiovascular disease being the most common $(12,21)$, co-occurring in $50 \%$ of patients (12). Of note, while the overall mortality in patients with acromegaly has decreased, the biochemical control of disease activity with normalized GH and IGF-I does not always correlate with clinical well-being (10). Findings from a Polish cohort suggest that acromegaly disease activity is correlated with metabolic comorbidities rather than disease duration (22). Therefore, managing comorbidities concomitantly with biochemical disease activity control is an important issue, although control of GH and age-related IGF-I levels remains the cornerstone of treatment (10).

Indeed, advances in the clinical management of the disease can go some way to addressing the issue of comorbidities, as demonstrated in a single-center study performed in Croatia (23). Data spanning three decades of acromegaly management in France indicate that the proportion of patients who achieve disease control with medical therapy has increased over time. In these patients, the incidence of comorbidities is low, with life expectancy close to that in the general population (24). Ongoing vigilance for comorbidities is required to maintain this progress and could be supported by screening for other uncommon "hidden" comorbidities. A recent study of 106 patients with acromegaly and matched healthy controls indicated a surprisingly high incidence of bone damage, sometimes asymptomatic, in patients with acromegaly. It is of particular interest that vertebral fracture was identified in 13 acromegalic patients, compared with 4 in the control group (25). Similarly, Mazziotti et al. (2013) demonstrated a significantly higher incidence of vertebral fractures among patients with prolonged active acromegaly duration compared with controls (26). A study from Slovakia recently reported that vertical fractures occur despite disease control and are best predicted by cortical volumetric bone mineral density (27). A study from Croatia has shown lower calcaneus quantitative ultrasound parameters and increased bone turnover in male patients with active acromegaly (28). Hepatic steatosis is another comorbidity that has recently been reported at relatively high rates in patients with acromegaly, though the studies included small numbers of patients $(29,30)$. Genetic markers that may help identify patients with increased risk from these comorbidities have been studied $(30,31)$.

The panel concluded that physician awareness of acromegalyassociated comorbidities must be improved, including asymptomatic "hidden" complications such as osteoporosis and vertebral fractures. In addition, the group emphasized the importance of concomitant management of these comorbidities in order to improve the quality of life and optimally control disease activity for patients with acromegaly.

\section{USE OF CLINICAL GUIDELINES IN THE REGION}

In general, international guidelines are followed wherever possible as these tend to be more up-to-date than local guidelines. For example, a treatment algorithm from a recently published consensus statement from the $11^{\text {th }}$ Acromegaly Consensus Conference is widely referred to in clinical practice internationally, including in the countries considered in this review (32). One exception is Ukraine, where clinical practice aligns where possible with the Endocrine Society guidelines, depending on the availability of medications (33). Local guidelines are followed in countries where these are available and up-to-date, such as Poland and Russia $(34,35)$.

\section{CLINICAL CARE: VARIATION ACROSS THE REGION}

Similar principles of best clinical practice are followed across the region, however, there are some minor differences in the specific treatment modalities as identified by the expert panel (Table 2). Moreover, the panel reported several factors that might influence treatment approaches from country-to-country, including availability, the proximity to neurosurgery and radiosurgery centers, and treatment reimbursement (Table 3).

Published reports from the region also indicate differences in the clinical treatment and management of patients with acromegaly, which may impact on patient outcomes. For example, a recent study reporting data from a Romanian tertiary care center disclosed that improvements to disease control had been attributed to changes in reimbursement for second-line pharmacological treatment options as well as increased referrals of pituitary surgery to specialist centers (36). Notably, in Poland and in some regions of Russia, where the availability of expert neurosurgeons is limited, the use of presurgical treatment such as somatostatin receptor ligands (SRLs) are more common (34). Cumbersome applications for reimbursement may also limit options for pharmacological treatment in many countries in the region, as is the case with long-acting pasireotide (PAS-LAR) and pegvisomant (PEGV) (37). Considering that pharmacological treatment represents a pivotal modality in managing uncontrolled acromegaly postoperatively, these limitations to optimal management are likely to have unfavorable outcomes and might be less costeffective in the long term (38). However, data on the costeffectiveness of medical therapies are relatively limited (39).

The panel concluded that treatment should be according to acceptable worldwide guidelines and that surgery should be the first-line treatment modality for operable acromegalic patients.

\section{KEY CLINICAL CONSIDERATIONS}

According to the guidelines, the neurosurgical approach represents first-line modality of treatment, and this is common 
TABLE 2 | Different treatment modalities according to the panel experts from CEE, Israel, and Kazakhstan.

\begin{tabular}{|c|c|c|c|c|c|c|}
\hline Country & First line & Second line & Third line & Fourth line & Fifth line & Notes \\
\hline Croatia & Surgery & $\begin{array}{l}\text { First-generation } \\
\text { SRL or DA in } \\
\text { selected patients }\end{array}$ & $\begin{array}{l}\text { First-generation SRL + } \\
\text { PEGV or first-generation } \\
\text { SRL + DA or PAS-LAR } \\
\text { monotherapy or PEGV } \\
\text { monotherapy (in SRL non- } \\
\text { responders) }\end{array}$ & $\begin{array}{l}\text { First-generation SRL } \\
+ \text { PEGV + DA }\end{array}$ & & $\begin{array}{l}\text { Radiosurgery is considered to be } \\
\text { an option at every stage of } \\
\text { treatment }\end{array}$ \\
\hline $\begin{array}{l}\text { Czech } \\
\text { Republic }\end{array}$ & Surgery & $\begin{array}{l}\text { Gamma knife } \\
\text { radiosurgery } \\
\text { (Leksell gamma } \\
\text { knife; linear } \\
\text { accelerator) + } \\
\text { pharmacotherapy }\end{array}$ & $\begin{array}{l}\text { Cabergoline (in patients with } \\
\text { mild disease activity) or } \\
\text { First-generation SRL or } \\
\text { first-generation SRL + } \\
\text { cabergoline or PAS-LAR }\end{array}$ & $\begin{array}{l}\text { PEGV or PEGV + } \\
\text { first-generation SRL } \\
\text { or PEGV + } \\
\text { cabergoline }\end{array}$ & & \\
\hline Israel & Surgery & $\begin{array}{l}\text { First-generation } \\
\text { SRL }\end{array}$ & $\begin{array}{l}\text { First-generation SRL + } \\
\text { PEGV } \pm \text { cabergoline or } \\
\text { PEGV or PAS-LAR }\end{array}$ & & & $\begin{array}{l}\text { Radiosurgery is considered to be } \\
\text { an option at every stage of } \\
\text { treatment }\end{array}$ \\
\hline Kazakhstan & Surgery & $\begin{array}{l}\text { First-generation } \\
\text { SRL }\end{array}$ & First-generation SRL + DA & Radiosurgery & & \\
\hline Poland & $\begin{array}{l}\text { First-generation SRL } \\
\text { (before surgery) }\end{array}$ & Surgery & $\begin{array}{l}\text { First-generation SRL (as } \\
\text { first pharmacotherapy after } \\
\text { surgery) }\end{array}$ & $\begin{array}{l}\text { PAS-LAR or PEGV } \\
\text { (therapeutic program) }\end{array}$ & $\begin{array}{l}\text { PEGV + first- } \\
\text { generation } \\
\text { SRL }\end{array}$ & $\begin{array}{l}\text { Repeat surgery is considered at } \\
\text { every stage of treatment. } \\
\text { Stereotactic radiosurgery is } \\
\text { considered when surgery has } \\
\text { failed }\end{array}$ \\
\hline Serbia & Surgery & $\begin{array}{l}\text { First-generation } \\
\text { SRL }\end{array}$ & $\begin{array}{l}\text { First-generation SRL + } \\
\text { cabergoline }\end{array}$ & $\begin{array}{l}\text { PAS-LAR or PEGV } \\
\text { monotherapy or } \\
\text { combination } \\
\text { treatment }\end{array}$ & & $\begin{array}{l}\text { Radiosurgery is considered if } \\
\text { pharmacological treatment is } \\
\text { ineffective }\end{array}$ \\
\hline Slovakia & $\begin{array}{l}\text { Surgery (sometimes } \\
\text { with debulking } \\
\text { treatment using SRL) }\end{array}$ & $\begin{array}{l}\text { First-generation } \\
\text { SRL }\end{array}$ & $\begin{array}{l}\text { First-generation SRL + } \\
\text { PEGV }\end{array}$ & $\begin{array}{l}\text { Gamma knife } \\
\text { radiosurgery or } \\
\text { second surgery }\end{array}$ & & \\
\hline Slovenia & Surgery & $\begin{array}{l}\text { First-generation } \\
\text { SRL }\end{array}$ & $\begin{array}{l}\text { First-generation SRL + } \\
\text { PEGV or PEGV } \\
\text { monotherapy or PAS-LAR } \\
\text { monotherapy }\end{array}$ & PAS-LAR + PEGV & & $\begin{array}{l}\text { Radiosurgery used in selected } \\
\text { cases after initial surgery. } \\
\text { Cabergoline used in patients with } \\
\text { mild disease, either as } \\
\text { monotherapy or in combination } \\
\text { with first-generation SRLs or } \\
\text { PEGV. } \\
\text { PAS-LAR is typically used in young } \\
\text { patients without diabetes, who } \\
\text { show signs of continued tumor } \\
\text { growth, experience persistent } \\
\text { headaches, or are intolerant to } \\
\text { PEGV. }\end{array}$ \\
\hline
\end{tabular}


TABLE 2 | Continued

\begin{tabular}{|c|c|c|c|c|c|c|}
\hline Country & First line & Second line & Third line & Fourth line & Fifth line & Notes \\
\hline Ukraine & Surgery & $\begin{array}{l}\text { First-generation } \\
\text { SRL or PEGV or } \\
\text { radiosurgery }\end{array}$ & $\begin{array}{l}\text { Repeat surgery or } \\
\text { combined medical } \\
\text { treatment }\end{array}$ & Repeat radiosurgery & $\begin{array}{l}\text { Temozolomide } \\
\text { for aggressive } \\
\text { tumors }\end{array}$ & $\begin{array}{l}\text { Cabergoline in patients with mild } \\
\text { disease }\end{array}$ \\
\hline
\end{tabular}

DA, dopamine agonist; SRL, somatostatin receptor ligand; PAS-LAR, long-acting pasireotide; PEGV, pegvisomant.

practice in Bulgaria, Croatia, the Czech Republic, Hungary, Israel, Kazakhstan, Romania, Serbia, Slovenia, Ukraine, and in some Russian regions where qualified pituitary surgeons are available (Moscow and surrounding regions such as SanktPetersburg, Tatarstan). For patients with uncontrolled postoperative acromegaly, the panel discussed some differences in pharmacological treatment between the 2020 Pituitary Society updates to the acromegaly management guidelines and everyday clinical practice in the region (40).

According to the consensus statement, treatment with firstgeneration long-acting SRLs such as octreotide LAR or lanreotide autogel, with dose escalation for partial responders, represents first-line pharmacological treatment (17). However, it is well known that the proportion of patients who achieve a complete response is suboptimal. According to a recently published retrospective study from a tertiary medical center in Bulgaria, 50\% (59/118) of the patients achieved disease control using treatment with a single-agent SRL (21). The expert panel agreed that increasing the dose of an SRL was thought to be ineffective in most patients and is not always attempted in clinical practice considering that only a small proportion of partial responders are likely to achieve a complete response with a higher dose. This was also observed in a 24-week prospective, randomized, open-label study of high-dose vs. high-frequency lanreotide autogel in partial responders after $>6$ months of SLR treatment. Treatment with either regimen achieved less than one-third normalization of IGF-I, with no significant difference in efficacy between high-dose vs. highfrequency (41). Similar data were reported in a prospective, randomized study using PAS-LAR vs. octreotide LAR. Despite up-titration being permitted in either treatment arm, fewer than $30 \%$ achieved biochemical control at 12 months by dose uptitration (42).

The option of multiple treatment modalities for second-line pharmacological treatment such as PAS-LAR and PEGV as monotherapy or in combination with first-generation SRLs allows for treatment individualization and disease control optimization. Key points to be considered when choosing treatment should include the extent of residual tumor, impaired glucose tolerance or new-onset diabetes, and whether the patient has experienced any side effects related to treatment.

PAS-LAR has been shown to provide sustained efficacy in a small proportion of patients treated previously with maximum doses of first-generation SRLs (43). In a Phase IIIb, open-label study of PAS-LAR, most adverse events were related to hyperglycemia. While almost all patients had diabetes or prediabetes at baseline, $63 \%$ of patients required antidiabetic treatment during the study, compared with only $25 \%$ of patients at baseline (43). As a result of PAS-LAR-induced hyperglycemia, some countries such as Serbia, Slovenia, and Croatia profile patients to determine who may benefit from second-line treatment such as PAS-LAR and PEGV. Furthermore, strategies to mitigate and monitor PAS-LARinduced hyperglycemia have been published recently (44). In Romania, PAS-LAR is considered a second-line option, glucose levels are monitored regularly, antidiabetic treatment is initiated in the case of new-onset diabetes and treatment with PAS-LAR can be switched to PEGV monotherapy in the presence of persistent hyperglycemia. PAS-LAR treatment is not considered in patients with uncontrolled diabetes in Israel, Poland, and Hungary. Owing to concerns about side effects of PAS-LAR, some clinicians avoid using PAS-LAR in patients who have not achieved a response with first-generation SRLs, instead recommending a combination of first-generation SRLs and PEGV or PEGV monotherapy. It is also noteworthy that PASLAR was considered an optional modality of treatment for patients with uncontrolled acromegaly who experience persistent headaches (45). The experts note that treatment availability should be considered, for example, PAS-LAR is not yet available in Russia, Kazakhstan, or Ukraine.

In contrast to SRLs, PEGV appears to improve glucose metabolism, as reported in a recently published meta-analysis that included 18 prospective studies. This meta-analysis showed that PEGV significantly decreased fasting plasma glucose (FPG) and glycated hemoglobin $\left(\mathrm{HbA}_{1 \mathrm{c}}\right)$ and that its effect on FPG was independent of its effect on IGF-I levels (46). However, when PEGV was used in combination with an SRL, the overall effect on glucose metabolism appeared to be neutral (46). Given the observational data supporting its long-term efficacy, PEGV is a key pharmacological option in this treatment setting (47). Nonetheless, careful clinical monitoring and proactive management - including dose adjustment - are needed to optimize disease control; for example, a recently published meta-analysis that demonstrated the effectiveness of PEGV monotherapy in real-world studies to be $71.7 \%$ (64.0-78.4\%; $95 \% \mathrm{CI}$ ), which is not as high as may be expected from the results of interventional studies (48). Another consideration is whether PEGV could promote pituitary tumor growth, given its unique mechanism of action. Published evidence from a long-term observational study has been reassuring (47). However, treatment decisions should always take the size and aggressiveness of the adenoma, and its response to previous treatment, into account (49). This is reflected in treatment approaches in many countries in the region, where PEGV is not used as monotherapy to treat patients with large or growing tumors.

Finally, another consideration in first- and second-line pharmacological therapy is cabergoline, which is used in 
TABLE 3 | Multidisciplinary centers, treatment availability, and interdisciplinary pituitary boards according to the panel experts from CEE, Israel, and Kazakhstan.

\begin{tabular}{|c|c|c|c|c|c|c|}
\hline $\begin{array}{l}\text { Country } \\
\text { (approximate } \\
\text { total } \\
\text { population*) }\end{array}$ & $\begin{array}{l}\text { Number of multidisciplinary } \\
\text { sites with on-site neuro- } \\
\text { surgery (A), endocrinology } \\
\text { (B) and radiotherapy (C) }\end{array}$ & $\begin{array}{l}\text { Estimated disease } \\
\text { control rates }\end{array}$ & $\begin{array}{l}\text { Availability/ } \\
\text { reimbursement } \\
\text { of first- } \\
\text { generation SRL }\end{array}$ & $\begin{array}{l}\text { Availability/ } \\
\text { reimbursement } \\
\text { of PEGV }\end{array}$ & $\begin{array}{l}\text { Availability/ } \\
\text { reimbursement } \\
\text { of PAS-LAR }\end{array}$ & $\begin{array}{l}\text { Regular interdisciplinary } \\
\text { pituitary boards at institutional } \\
\text { (I), local (L), or regional level (R) } \\
\text { and patient advocacy group }\end{array}$ \\
\hline $\begin{array}{l}\text { Bulgaria } \\
\text { (7.3 million) }\end{array}$ & $\begin{array}{l}\text { A } 1 \\
\text { B } 1 \\
\text { C } 1\end{array}$ & $84.3 \%$ & $\begin{array}{l}\text { Octreotide LAR } \\
\text { monotherapy }\end{array}$ & $\begin{array}{l}\text { PEGV } \\
\text { monotherapy/ } \\
\text { combination with } \\
\text { SRL }\end{array}$ & $\begin{array}{l}\text { PAS-LAR } \\
\text { monotherapy/ } \\
\text { combination with } \\
\text { PEGV }\end{array}$ & $\begin{array}{l}\text { I, L } \\
\text { Pituitary Association, Association } \\
\text { of Acromegaly Patients in Bulgaria }\end{array}$ \\
\hline $\begin{array}{l}\text { Croatia } \\
\text { (4.4 million) }\end{array}$ & $\begin{array}{l}\text { A } 2 \\
\text { B } 1 \\
\text { C } 1\end{array}$ & $\begin{array}{l}\text { 95\% (unpublished data } \\
\text { from Croatian } \\
\text { acromegaly registry) }\end{array}$ & $\begin{array}{l}\text { First-generation } \\
\text { SRL monotherapy }\end{array}$ & $\begin{array}{l}\text { PEGV } \\
\text { monotherapy/ } \\
\text { combination with } \\
\text { SRL }\end{array}$ & $\begin{array}{l}\text { PAS-LAR } \\
\text { monotherapy/ } \\
\text { combination with } \\
\text { PEGV or } \\
\text { cabergoline }\end{array}$ & $\begin{array}{l}\text { I (at one center) } \\
\text { No patient advocacy groups }\end{array}$ \\
\hline $\begin{array}{l}\text { Czech } \\
\text { Republic } \\
\text { (10.5 million) }\end{array}$ & $\begin{array}{l}\text { A } 7 \\
\text { B } 5 \\
\text { C } 5\end{array}$ & $\begin{array}{l}\text { Estimated surgical } \\
\text { cure rate } 50-60 \% \text {, } \\
\text { pharmacotherapy } \\
\text { disease control in the } \\
\text { majority }\end{array}$ & $\begin{array}{l}\text { First-generation } \\
\text { SRL } \\
\text { monotherapy/ } \\
\text { combination with } \\
\text { cabergoline }\end{array}$ & $\begin{array}{l}\text { PEGV } \\
\text { monotherapy/ } \\
\text { combination with } \\
\text { SRL or } \\
\text { cabergoline }\end{array}$ & $\begin{array}{l}\text { Reimbursed after } \\
\text { approval of } \\
\text { health insurance } \\
\text { company }\end{array}$ & $\begin{array}{l}\mathrm{I}, \mathrm{L} \text {, and } \mathrm{R} \\
\text { No patient advocacy groups }\end{array}$ \\
\hline $\begin{array}{l}\text { Hungary } \\
\text { (9.9 million) }\end{array}$ & $\begin{array}{l}\text { A } 4 \\
\text { B } 5 \\
\text { C } 4\end{array}$ & $75 \%$ & $\begin{array}{l}\text { First-generation } \\
\text { SRL } \\
\text { monotherapy/ } \\
\text { combination with } \\
\text { cabergoline }\end{array}$ & $\begin{array}{l}\text { PEGV } \\
\text { monotherapy/ } \\
\text { combination with } \\
\text { SRL or DA }\end{array}$ & $\begin{array}{l}\text { PAS-LAR } \\
\text { monotherapy/ } \\
\text { combination with } \\
\text { PEGV }\end{array}$ & No patient advocacy groups \\
\hline $\begin{array}{l}\text { Israel } \\
\text { (9.3 million) }\end{array}$ & $\begin{array}{l}\text { A } 7 \\
\text { B } 6 \\
\text { C } 6\end{array}$ & $87 \%$ & $\begin{array}{l}\text { First-generation } \\
\text { SRL monotherapy }\end{array}$ & $\begin{array}{l}\text { PEGV } \\
\text { monotherapy/ } \\
\text { combination with } \\
\text { SRL }\end{array}$ & $\begin{array}{l}\text { PAS-LAR } \\
\text { monotherapy }\end{array}$ & $\begin{array}{l}\text { I, L and annual acromegaly patient } \\
\text { day }\end{array}$ \\
\hline $\begin{array}{l}\text { Kazakhstan } \\
\text { (19.0 million) }\end{array}$ & $\begin{array}{l}\text { A } 3 \\
\text { B } 1 \\
\text { C } 1\end{array}$ & $\begin{array}{l}\text { Estimated rate cured } \\
\text { by surgery: } 50 \%\end{array}$ & $\begin{array}{l}\text { First-generation } \\
\text { SRL monotherapy }\end{array}$ & Not reimbursed & Not reimbursed & 1 \\
\hline $\begin{array}{l}\text { Poland } \\
\text { (38.1 million) }\end{array}$ & $\begin{array}{l}\text { A5 } \\
\text { B12 } \\
\text { C } 2\end{array}$ & $75 \%$ & $\begin{array}{l}\text { Therapy with first- } \\
\text { generation } S R L \\
\text { reimbursed }\end{array}$ & $\begin{array}{l}\text { Available in } \\
\text { medication } \\
\text { program }\end{array}$ & $\begin{array}{l}\text { Available in } \\
\text { medication } \\
\text { program }\end{array}$ & $\begin{array}{l}\text { Annual acromegaly patient day } \\
\text { Patient advocacy group }\end{array}$ \\
\hline $\begin{array}{l}\text { Romania } \\
\text { (19.2 million) }\end{array}$ & $\begin{array}{l}\text { A } 3 \\
\text { B } 3 \\
\text { C } 1\end{array}$ & $52 \%$ & $\begin{array}{l}\text { First-generation } \\
\text { SRL monotherapy }\end{array}$ & $\begin{array}{l}\text { PEGV } \\
\text { monotherapy/ } \\
\text { combination with } \\
\text { SRL or DA }\end{array}$ & $\begin{array}{l}\text { PAS-LAR } \\
\text { monotherapy/ } \\
\text { combination with } \\
\text { PEGV or } \\
\text { cabergoline }\end{array}$ & $\begin{array}{l}\text { Monthly multidisciplinary meetings } \\
\text { (L). Tumor board ad hoc meetings } \\
\text { (L) Patient website (Romanian } \\
\text { Society for Endocrinology) (I) }\end{array}$ \\
\hline $\begin{array}{l}\text { Russia } \\
\text { (146.2 million) }\end{array}$ & $\begin{array}{l}\mathrm{A} 6 \\
\mathrm{~B} 10 \\
\mathrm{C} 2\end{array}$ & $24-50 \%$ & $\begin{array}{l}\text { First-generation } \\
\text { SRL } \\
\text { monotherapy/ } \\
\text { combination with } \\
\text { DA }\end{array}$ & Reimbursed & Not available & I, L, and R Velikan patient society \\
\hline $\begin{array}{l}\text { Serbia }^{\dagger} \\
\text { (6.9 million) }\end{array}$ & $\begin{array}{l}\text { A } 2 \\
\text { B } 2 \\
\text { C } 2\end{array}$ & $\sim 70 \%$ & $\begin{array}{l}\text { First-generation } \\
\text { SRL } \\
\text { monotherapy/ } \\
\text { combination with } \\
\text { DA }\end{array}$ & $\begin{array}{l}\text { PEGV } \\
\text { reimbursed }\end{array}$ & $\begin{array}{l}\text { PAS-LAR } \\
\text { reimbursed }\end{array}$ & $\begin{array}{l}\text { Acromegaly patient society } \\
\text { (UPAK-Udruzenje pacijenata sa } \\
\text { akromegalijom) https://upak.rs }\end{array}$ \\
\hline $\begin{array}{l}\text { Slovakia } \\
\text { (5.4 million) }\end{array}$ & $\begin{array}{l}\text { A } 4 \\
\text { B } 4 \\
\text { C } 0\end{array}$ & $\begin{array}{l}60-75 \% \text { after TSS for } \\
\text { microadenoma and } \\
50 \% \text { for } \\
\text { macroadenoma. } \\
75 \% \text { in combination } \\
\text { with medical therapy }\end{array}$ & $\begin{array}{l}\text { First-generation } \\
\text { SRL monotherapy }\end{array}$ & PEGV & PAS-LAR & \\
\hline $\begin{array}{l}\text { Slovenia } \\
\text { (2.1 million) }\end{array}$ & $\begin{array}{l}\text { A } 1 \\
\text { B } 2 \\
\text { C } 0\end{array}$ & $80 \%$ & $\begin{array}{l}\text { First-generation } \\
\text { SRL } \\
\text { monotherapy/ } \\
\text { combination with } \\
\text { DA }\end{array}$ & $\begin{array}{l}\text { PEGV } \\
\text { monotherapy/ } \\
\text { combination with } \\
\text { SRL or DA }\end{array}$ & $\begin{array}{l}\text { PAS-LAR } \\
\text { monotherapy/ } \\
\text { combination with } \\
\text { PEGV }\end{array}$ & $\begin{array}{l}\text { Monthly (I) and biannual (R) } \\
\text { multidisciplinary meetings/ } \\
\text { Not established }\end{array}$ \\
\hline $\begin{array}{l}\text { Ukraine } \\
\text { (45.1million) }^{\ddagger}\end{array}$ & $\begin{array}{l}\text { A } 1 \\
\text { B } 1 \\
\text { C } 4\end{array}$ & Unknown & $\begin{array}{l}\text { First-generation } \\
\text { SRLs are partially } \\
\text { reimbursed from } \\
\text { regional budgets }\end{array}$ & $\begin{array}{l}\text { PEGV is partially } \\
\text { reimbursed from } \\
\text { regional budgets }\end{array}$ & $\begin{array}{l}\text { Available for } \\
\text { administration, } \\
\text { without } \\
\text { reimbursement }\end{array}$ & $\begin{array}{l}\text { Regular interdisciplinary pituitary } \\
\text { boards at institutional (I), local (L) } \\
\text { or (R) at meetings and } \\
\text { conferences. } \\
\text { NGO "Rare Diseases of Ukraine" } \\
\text { (http://rarediseases.org.ua/) }\end{array}$ \\
\hline
\end{tabular}

*Source: https://www.economist.com/node/21566456. Updated Nov 2012. Accessed 05 August 2021.

${ }^{\dagger}$ Source: https://www.stat.gov.rs/en-us/oblasti/stanovnistvo/procene-stanovnistva/. Updated July 2021. Accessed 5 Aug 2021.

${ }^{\ddagger} 45.1$ million demographic maximum. In 2019 an electronic census estimated that Ukraine's population, excluding occupied territories to be 37.3 million.

$D A$, dopamine agonist; SRL, somatostatin receptor ligand; PAS-LAR, long-acting pasireotide. 
responsive patients with mild disease activity, either as monotherapy or in combination with first-generation SRLs or PEGV.

The rationale for combined treatment as second-line pharmacological therapy is that the addition of another modality of treatment with a different mechanism of action is more likely to show an additive effect than dose escalation of the ongoing treatment or switching compound altogether especially for patients showing a partial response to first-line pharmacological treatment. This is supported by a recently published network meta-analysis of simulated trials generated by an algorithm, which indicated that combination therapy with PEGV and SRL was the most effective medical treatment option overall (50). Indeed, findings from the non-interventional ACROSTUDY show that the proportion of patients receiving combination treatment increased from $20 \%$ in 2003 to $54 \%$ in 2012 (51), with the trend likely continuing as pharmacological treatment options increase and become more widely reimbursed.

The role of radiotherapy and radiosurgery in patients who have not achieved biochemical control of acromegaly varies by location, reflecting differences in access to specialist centers and waiting times across CEE, Israel, and Kazakhstan. However, published data from other countries indicate that increased access across the region in question would have considerable potential to improve patient outcomes. For example, in a retrospective study of 352 patients in the German Acromegaly Registry, approximately three-quarters of patients were in remission or had controlled disease ten years after fractionated radiotherapy (FRT) or stereotactic radiosurgery (SRS). However, care is needed to avoid hypopituitarism. In this study, the rate of pituitary insufficiency was significantly higher after FRT (52). Another retrospective study including 371 patients across ten centers, including some in the Czech Republic, supports the efficacy of SRS in persistent or recurrent disease, showing an actuarial durable remission rate of $59 \%$ at ten years (53). The use of radiosurgery in the management of acromegaly also permits patients to reduce and eventually stop pharmacotherapy in the long term; the median time to normalization of IGF-I in one study of radiosurgery was 54 months (54). This is likely to have clear benefits for patients, as well as pharmacoeconomic benefits.

\section{TESTING AT BASELINE AND FOLLOW-UP}

After primary surgery, MRI scans to assess tumor volume are performed as early as 12 hours after surgery in some specialist centers, but typically at around three months, providing a baseline for future reference. After this, imaging is carried out at tailored time intervals based on tumor status, $\mathrm{GH}$, and IGF-I response.

$\mathrm{GH}$ and IGF-I testing are the cornerstones of acromegaly diagnosis and subsequent monitoring of disease activity (55). Improvements have been made to assays for each of these, making them more sensitive and reliable on the whole. However, reference ranges and clinical thresholds still vary between assays, for example, in Poland, active acromegaly is diagnosed when IGF-1 levels are above $1.0 \times \mathrm{ULN}$ and GH suppression is not below $1.0 \mu \mathrm{g} / \mathrm{L}$ using oral glucose tolerance tests (OGTTs) or below $0.4 \mathrm{mg} / \mathrm{L}$ using ultrasensitive $\mathrm{GH}$ assays (34). In Croatia and Slovenia, a GH cut-off of $0.4 \mu \mathrm{g} / \mathrm{L}$ is also used for diagnosis. Standardization of when and how to test GH and IGF-I levels during diagnosis and follow-up would substantially improve the clinical management of acromegaly, providing information of consistent quality on which to base treatment decisions.

IGF-I tests are generally done every six months after surgery in patients with well-controlled disease. IGF-I assay results can vary with the assay used and the laboratory that performs it (56). Therefore, these findings support using the same assay throughout one patient's diagnosis and follow-up. To aid consistent interpretation of IGF-I test outputs, many specialist centers develop their database and reference range for adults by sex and age group, based on consistent use of a specific assay. Tests should be performed exclusively at the reference laboratory, and training and education of laboratory specialists are also recommended to enhance the consistency of test outputs.

A similar principle applies to $\mathrm{GH}$ testing, in which the need for consistency also extends to reference ranges. GH nadir concentrations during OGTTs using sensitive GH assays were recently reviewed, and normal values were lower than the thresholds specified in previous acromegaly guidelines and variable according to body mass index, sex, and oral contraceptive use.

\section{DISEASE CONTROL ACROSS CEE, ISRAEL, AND KAZAKHSTAN}

Despite different treatment modalities, disease control remains a challenge for many patients treated in this region. Data from a Russian registry reported that the proportions of patients undergoing neurosurgical treatment increased from $36 \%$ to $50 \%$ in 2012-2019, while the proportion of patients undergoing radiation therapy decreased from $17.7 \%$ to $0.8 \%$ in the same period (57). This study also reported remission rates of $40 \%$ after neurosurgery and $29 \%$ after medical treatment as firstline therapy $(\mathrm{p}<0.01)$. Retrospective data from 147 patients treated in Romania who had been assessed at least once at a tertiary referral center, showed $29 \%$ disease control - defined as random serum $\mathrm{GH}<1 \mu \mathrm{g} / \mathrm{L}$ and age-normalized serum IGF-I. Of these, more than $90 \%$ had undergone surgery, and $~ 80 \%$ were receiving pharmacological treatment with SRLs (58). More recent published studies have shown that the proportion of patients with biochemical control is already being improved: another study performed in Romania demonstrated that $46.7 \%$ of the participants achieved disease control (34); a retrospective study from 191 patients of a tertiary center in Bulgaria demonstrated $84 \%$ disease control, with the most common pharmacotherapies used after surgery being single-agent longacting SLRs (38\%) or combination therapy with PEGV and an SLR (12\%). As would be expected, treatment with combination 
therapy appeared to be more common in patients who had longer disease duration (21). The potential for achieving high response rates with carefully tailored pharmacotherapy is further highlighted by a recent retrospective study in Israel, which reported good biochemical control in $87 \%$ of a cohort of 87 patients with active acromegaly who underwent medical treatment, most after surgery failure (59). The above-reported data demonstrated an improvement in the management of acromegaly and disease control activity across CEE, Israel, and Kazakhstan.

The expert panel concluded that to achieve better disease control, there is a need for systematic evaluation of disease activity based on multiple parameters, including the use of defined tools such as the Acromegaly Disease Activity Tool $\left(\right.$ ACRODAT $\left.^{\circledR}\right)$, which includes IGF-I level, tumor status, symptoms, comorbidities, and quality of life (60). Another such multidimensional instrument is SAGIT ${ }^{\circledR}$, which covers a combination of clinical and biochemical features, including signs and symptoms (S), associated comorbidities (A), GH levels (G), IGF-I levels (I), and tumor profile (T) $(61,62)$. Acromegaly-specific patient-reported outcomes, such as those included in the Acro-TSQ score, could also provide valuable insights to guide tailored patient care at specific points in the treatment algorithm (63). Unfortunately, these tools, like diagnostic tools such as ACROSCORE, have not been widely adopted in the region, likely again due to lack of translations into local languages and consequent low awareness.

Patient-centered, multidisciplinary care should be the foundation that supports improvements to diagnosis, followup, management of comorbidities, and patient quality of life. Multidisciplinary care is already underway across CEE, Israel, and Kazakhstan. Typically, the pituitary multidisciplinary team includes an endocrinologist, neurosurgeon, pathologist, and radiologist. In the Czech Republic and Croatia, this multidisciplinary team also includes a specialist in stereotactic surgery; in Serbia, it includes a geneticist. Provision of care via specialist centers varies widely across the region, with some countries having more specialist pituitary centers per capita of the population than others (Table 1). Finally, systematic data collection in national or regional registries would support identifying and exchanging of best practices and better screening for and management of comorbidities. Registries

\section{REFERENCES}

1. Maione L, Chanson P. National Acromegaly Registries. Best Pract Res Clin Endocrinol Metab (2019) 33:101264. doi: 10.1016/j.beem.2019.02.001

2. Caron P, Brue T, Raverot G, Tabarin A, Cailleux A, Delemer B, et al. Signs and Symptoms of Acromegaly at Diagnosis: The Physician's and the Patient's Perspectives in the ACRO-POLIS Study. Endocrine (2019) 63:120-9. doi: 10.1007/s12020-018-1764-4

3. Colao A, Grasso LFS, Giustina A, Melmed S, Chanson P, Pereira AM, et al. Acromegaly. Nat Rev Dis Primers (2019) 5:20. doi: 10.1038/s41572-019-0071-6

4. Petrossians P, Daly AF, Natchev E, Maione L, Blijdorp K, Sahnoun-Fathallah $\mathrm{M}$, et al. Acromegaly at Diagnosis in 3173 Patients From the Liege Acromegaly Survey (LAS) Database. Endocr Relat Cancer (2017) 24:505-18. doi: 10.1530/ERC-17-0253 could also potentially include specific reporting requirements for test results, facilitating widespread standardization and allowing comparison between patients. Data from registries could also be used to inform and support reimbursement requests or policies.

\section{CONCLUSIONS}

The management of acromegaly across CEE, Israel, and Kazakhstan has been advanced in the last decade. However, there is a need for further improvement in this field, including early diagnosis by increasing disease awareness among nonendocrinologist healthcare practitioners; standardized tools for disease activity evaluation; the systematic gathering of data in national registries for precise data reporting, including prevalence and other parameters. Furthermore, the panel revealed the importance of multidisciplinary disease management and treatment accessibility for surgical and pharmacologic therapies. The continued exchange of best practices in these areas can support optimizing patient care across the region.

\section{AUTHOR CONTRIBUTIONS}

All authors contributed to the advisory board discussions, critically reviewed all drafts of the manuscript and approved the final draft of the manuscript.

\section{FUNDING}

Pfizer supported the face-to-face advisory board meeting.

\section{ACKNOWLEDGMENTS}

Medical writing and editorial assistance were provided by Christine Elsner and Kyle Lambe (Synergy Medical Communications, London, UK), and was supported by Pfizer.

5. Dreval AV, Pokramovich YG, Nechaeva O, Shestakova T, Trigolosova IV, Ilovayskaya IA. Symptoms and Sign of Active Acromegaly in Patients From Moscow Region. In: Endocrine Society's 96th Annual Meeting and Expo. Chicago: Endocrine Reviews (2014). p. i1-i1153. June 21-24, 2014.

6. Khyzhnyak OM, Mykytyuk M, Guk M, Nikolaiev R, Gogitidze T. Clinical and Hormonal Features of Acromegaly in Patients From a Ukrainian Neuroendocrinology Centre. Prob Endocr Pathol (2019) 68:119-30. doi: 10.21856/j-PEP.2019.2.17

7. Nikolaiev RR, Rostomyan L, Beckers A, Tsymbaliuk V, Khyzhnyak O, Guk M, et al. Acromegaly Combined With Gigantism Associated With the AIP-Gene Mutation: A Clinical Case. Problems Endocrine Pathol (2021) 75:43-51. doi: 10.21856/j-PEP.2021.1.06.

8. Prencipe N, Floriani I, Guaraldi F, Di Giacomo SV, Cannavo S, Arnaldi G, et al. ACROSCORE: A New and Simple Tool for the Diagnosis of 
Acromegaly, a Rare and Underdiagnosed Disease. Clin Endocrinol (Oxf) (2016) 84:380-5. doi: 10.1111/cen.12959

9. Antsiferov MB, Pronin VS, Alekseeva TM, Ionova OA, Martynova EY, Poteshkin YE, et al. Selective Screening of Patients With Associated Somatic Diseases as a Method of Early Detection of Acromegaly. Probl Endokrinol (Mosk) (2021) 67:20-30. doi: 10.14341/probl12699

10. Giustina A, Barkan A, Beckers A, Biermasz N, Biller BMK, Boguszewski C, et al. A Consensus on the Diagnosis and Treatment of Acromegaly Comorbidities: An Update. J Clin Endocrinol Metab (2020) 105:e937-46. doi: 10.1210/clinem/dgz096

11. Colao A, Vandeva S, Pivonello R, Grasso LFS, Nachev E, Auriemma RS, et al. Could Different Treatment Approaches in Acromegaly Influence Life Expectancy? A Comparative Study Between Bulgaria and Campania (Italy). Eur J Endocrinol (2014) 171:263-73. doi: 10.1530/EJE-13-1022

12. Rolla M, Jawiarczyk-Przybylowska A, Halupczok-Zyla J, Kaluzny M, Konopka BM, Bloniecka I, et al. Complications and Comorbidities of AcromegalyRetrospective Study in Polish Center. Front Endocrinol (Lausanne) (2021) 12:642131. doi: 10.3389/fendo.2021.642131

13. Bolanowski M, Zgliczynski W, Sowinski J, Baldys-Waligorska A, BednarekTupikowska G, Witek P, et al. Therapeutic Effect of Presurgical Treatment With Longacting Octreotide (Sandostatin ${ }^{\circledR}$ LAR $^{\circledR}$ ) in Patients With Acromegaly. Endokrynol Pol (2020) 71:285-91. doi: 10.5603/EP.a2020.0050

14. Shestakova T, Dreval A, Nechaeva O, Zakharevich E, Ilovayskaya IA. Gender Differences in Thyroid Abnormalities at Patients With Acromegaly: SAT-748. In: The Endocrine Society's 94th Annual Meeting and Expo. Houston, TX: Endocrine Reviews (2012). p. i1-i1057. June 23-26, 2012.

15. Dreval AV, Trigolosova IV, Misnikova IV, Kovalyova YA, Tishenina RS, Barsukov IA, et al. Prevalence of Diabetes Mellitus in Patients With Acromegaly. Endocr Connect (2014) 3:93-8. doi: 10.1530/EC-14-0021

16. Baldys-Waligorska A, Krzentowska A, Golkowski F, Sokolowski G, Hubalewska-Dydejczyk A. The Prevalence of Benign and Malignant Neoplasms in Acromegalic Patients. Endokrynol Pol (2010) 61:29-34.

17. Tsoy UA, Korostovtseva LS, Sviryaev YV, Semenov AP, Vaulina DA, Kravchenko SO, et al. Prevalence of Sleep Disordered Breathing in Patients With Newly Diagnosed Acromegaly. Almanac Clin Med (2014) 32:36-42. doi: 10.18786/2072-0505-2014-32-36-42

18. Titaeva AA, Tereshchenko SG, Lukina EM, Dreval AV, Ilovaiskaya IA. Background Changes of the Digestive System Mucosa in Patients With Acromegaly. Almanac Clin Med (2014) 31:29-33. doi: 10.18786/2072-05052014-31-29-33

19. Kovaleva YA, Dreval AV, Kulakov NV, Fedorova SI, Ilovayskaya IA. Prevalence and Risk Factors of Sleep Breathing Disorders in Patients With Acromegaly From Moscow Region. Ter Arkh (2018) 90:65-70. doi: 10.26442/ terarkh2018901065-70

20. Dreval A, Logutova L, Zaydieva Y, Stashuk G, Perfilyev A, Ilovayskaya IA. Menstrual Function in Women of Reproductive Age With Acromegaly. Endocrine Abstracts (2013) 32:612. doi: 10.1530/endoabs.32.P612

21. Kamusheva M, Vandeva S, Mitov K, Rusenova Y, Elenkova A, Zacharieva S, et al. New Epidemiological, Clinical and Economic Data for Patients With Acromegaly in Bulgaria. Front Public Health (2020) 8:147. doi: 10.3389/ fpubh.2020.0014

22. Stelmachowska-Banas M, Zdunowski P, Zgliczynski W. Abnormalities in Glucose Homeostasis in Acromegaly. Does the Prevalence of Glucose Intolerance Depend on the Level of Activity of the Disease and the Duration of the Symptoms? Endokrynol Pol (2009) 60:20-4.

23. Dusek T, Kastelan D, Melada A, Baretic M, Skoric Polovina T, Perkovic Z, et al. Clinical Features and Therapeutic Outcomes of Patients With Acromegaly: Single-Center Experience. J Endocrinol Invest (2011) 34:e3825. doi: $10.3275 / 7858$

24. Maione L, Brue T, Beckers A, Delemer B, Petrossians P, Borson-Chazot F, et al. Changes in the Management and Comorbidities of Acromegaly Over Three Decades: The French Acromegaly Registry. Eur J Endocrinol (2017) 176:645-55. doi: 10.1530/EJE-16-1064

25. Kuzma M, Vanuga P, Sagova I, Pavai D, Jackuliak P, Killinger Z, et al. NonInvasive DXA-Derived Bone Structure Assessment of Acromegaly Patients: A Cross-Sectional Study. Eur J Endocrinol (2019) 180:201-11. doi: 10.1530/EJE18-0881
26. Mazziotti G, Bianchi A, Porcelli T, Mormando M, Maffezzoni F, Cristiano A, et al. Vertebral Fractures in Patients With Acromegaly: A 3-Year Prospective Study. J Clin Endocrinol Metab (2013) 98:3402-10. doi: 10.1210/jc.2013-1460

27. Kuzma M, Vanuga P, Sagova I, Pavai D, Jackuliak P, Killinger Z, et al. Vertebral Fractures Occur Despite Control of Acromegaly and are Predicted by Cortical Volumetric Bone Mineral Density. J Clin Endocrinol Metab (2021) 106:e5088-96. doi: 10.1210/clinem/dgab259

28. Kastelan D, Dusek T, Kraljevic I, Polasek O, Perkovic Z, Kardum I, et al. Bone Properties in Patients With Acromegaly: Quantitative Ultrasound of the Heel. J Clin Densitom (2007) 10:327-31. doi: 10.1016/j.jocd.2007.03.103

29. Ciresi A, Guarnotta V, Campo D, Giordano C. Hepatic Steatosis Index in Acromegaly: Correlation With Insulin Resistance Regardless of the Disease Control. Int J Endocrinol (2018) 2018:5421961. doi: 10.1155/2018/5421961

30. Koutsou-Tassopoulou A, Papapostoli-Sklavounou I, Krawczyk M, Friesenhahn-Ochs B, Weber SN, Lammert F, et al. Hepatic Steatosis in Patients With Acromegaly. Endocrinol Diabetes Metab (2019) 2:e00090. doi: $10.1002 / \mathrm{edm} 2.90$

31. Jawiarczyk-Przybylowska A, Halupczok-Zyla J, Kolackov K, Gojny L, Zembska A, Bolanowski M. Association of Vitamin D Receptor Polymorphisms With Activity of Acromegaly, Vitamin D Status and Risk of Osteoporotic Fractures in Acromegaly Patients. Front Endocrinol (Lausanne) (2019) 10:643. doi: 10.3389/fendo.2019.00643

32. Melmed S, Bronstein MD, Chanson P, Klibanski A, Casanueva FF, Wass JAH, et al. A Consensus Statement on Acromegaly Therapeutic Outcomes. Nat Rev Endocrinol (2018) 14:552-61. doi: 10.1038/s41574-018-0058-5

33. Katznelson L, Laws ER Jr, Melmed S, Molitch ME, Murad MH, Utz A, et al. Acromegaly: An Endocrine Society Clinical Practice Guideline. J Clin Endocrinol Metab (2014) 99:3933-51. doi: 10.1210/jc.2014-2700

34. Bolanowski M, Ruchala M, Zgliczynski W, Kos-Kudla B, HubalewskaDydejczyk A, Lewinski A. Diagnostics and Treatment of Acromegaly Updated Recommendations of the Polish Society of Endocrinology. Endokrynol Pol (2019) 70:2-18. doi: 10.5603/EP.a2018.0093

35. Molitvoslovova NN, Rozhinskaya LY, Melnichenko GA. [Russian Consensus on the Diagnosis, Treatment, and Monitoring of Acromegalia (Draft)]. Probl Endokrinol (Mosk) (2007) 53:37-41. doi: 10.14341/probl200753437-41

36. Marinescu MC, Baciu I, Baculescu N, Capatina CAM, Dusceac R, Galoiu S, et al. Improvement of Acromegaly Control With Multimodal Therapy in Romania. Endokrynol Pol (2020) 71:235-9. doi: 10.5603/EP.a2020.0020

37. Doknić M, Stojanović M. The Place of Medical Treatment of Acromegaly in Serbia: Current Status. Vojnosanitetski Pregled (2021) 78:1088-95. doi: 10.2298/VSP200120036D

38. Elbaum M, Mizera L, Bolanowski M. The Real Costs of Acromegaly: Analysis of Different Therapies. Endokrynol Pol (2019) 70:74-85. doi: 10.5603/ EP.a2018.0080

39. Leonart LP, Borba HHL, Ferreira VL, Riveros BS, Pontarolo R. CostEffectiveness of Acromegaly Treatments: A Systematic Review. Pituitary (2018) 21:642-52. doi: 10.1007/s11102-018-0908-0

40. Fleseriu M, Biller BMK, Freda PU, Gadelha MR, Giustina A, Katznelson L, et al. A Pituitary Society Update to Acromegaly Management Guidelines. Pituitary (2021) 24:1-13. doi: 10.1007/s11102-020-01091-7

41. Giustina A, Mazziotti G, Cannavò S, Castello R, Arnaldi G, Bugari G, et al. High-Dose and High-Frequency Lanreotide Autogel in Acromegaly: A Randomized, Multicenter Study. J Clin Endocrinol Metab (2017) 102:245464. doi: 10.1210/jc.2017-00142

42. Colao A, Bronstein MD, Freda P, Gu F, Shen CC, Gadelha M, et al. Pasireotide Versus Octreotide in Acromegaly: A Head-to-Head Superiority Study. J Clin Endocrinol Metab (2014) 99:791-9. doi: 10.1210/jc.2013-2480

43. Gadelha M, Bex M, Colao A, Pedroza Garcia EM, Poiana C, Jimenez-Sanchez $\mathrm{M}$, et al. Evaluation of the Efficacy and Safety of Switching to Pasireotide in Patients With Acromegaly Inadequately Controlled With First-Generation Somatostatin Analogs. Front Endocrinol (Lausanne) (2019) 10:931. doi: 10.3389/fendo.2019.00931

44. Coopmans EC, Muhammad A, van der Lely AJ, Janssen J, Neggers S. How to Position Pasireotide LAR Treatment in Acromegaly. J Clin Endocrinol Metab (2019) 104:1978-88. doi: 10.1210/jc.2018-01979

45. Shimon I, Adnan Z, Gorshtein A, Baraf L, Saba Khazen N, Gershinsky M, et al. Efficacy and Safety of Long-Acting Pasireotide in Patients With Somatostatin- 
Resistant Acromegaly: A Multicenter Study. Endocrine (2018) 62:448-55. doi: 10.1007/s12020-018-1690-5

46. Feola T, Cozzolino A, Simonelli I, Sbardella E, Pozza C, Giannetta E, et al. Pegvisomant Improves Glucose Metabolism in Acromegaly: A Meta-Analysis of Prospective Interventional Studies. J Clin Endocrinol Metab (2019) 104:2892-902. doi: 10.1210/jc.2018-02281

47. Buchfelder M, van der Lely AJ, Biller BMK, Webb SM, Brue T, Strasburger CJ, et al. Long-Term Treatment With Pegvisomant: Observations From 2090 Acromegaly Patients in ACROSTUDY. Eur J Endocrinol (2018) 179:419-27. doi: 10.1530/EJE-18-0616

48. Leonart LP, Tonin FS, Ferreira VL, Fernandez-Llimos F, Pontarolo R. Effectiveness and Safety of Pegvisomant: A Systematic Review and MetaAnalysis of Observational Longitudinal Studies. Endocrine (2019) 63:18-26. doi: 10.1007/s12020-018-1729-7

49. Giustina A, Arnaldi G, Bogazzi F, Cannavò S, Colao A, De Marinis L, et al. Pegvisomant in Acromegaly: An Update. J Endocrinol Invest (2017) 40:57789. doi: 10.1007/s40618-017-0614-1

50. Qiao N, He M, Shen M, Zhang Q, Zhang Z, Shou X, et al. Comparative Efficacy of Medical Treatment for Acromegaly: A Systematic Review and Network Meta-Analysis of Integrated Randomized Trials and Observational Studies. Endocr Pract (2020) 26:454-62. doi: 10.4158/EP-2019-0528

51. Strasburger CJ, Mattsson A, Wilton P, Aydin F, Hey-Hadavi J, Biller BMK. Increasing Frequency of Combination Medical Therapy in the Treatment of Acromegaly With the GH Receptor Antagonist Pegvisomant. Eur J Endocrinol (2018) 178:321-9. doi: 10.1530/EJE-17-0996

52. Knappe UJ, Petroff D, Quinkler M, Schmid SM, Schöfl C, Schopohl J, et al. Fractionated Radiotherapy and Radiosurgery in Acromegaly: Analysis of 352 Patients From the German Acromegaly Registry. Eur J Endocrinol (2020) 182:275-84. doi: 10.1530/EJE-19-0784

53. Ding D, Mehta GU, Patibandla MR, Lee CC, Liscak R, Kano H, et al. Stereotactic Radiosurgery for Acromegaly: An International Multicenter Retrospective Cohort Study. Neurosurgery (2019) 84:717-25. doi: 10.1093/neuros/nyy178

54. Ježkova J, Marek J, Hána V, Kršek M, Weiss V, Vladyka V, et al. Gamma Knife Radiosurgery for Acromegaly-Long-Term Experience. Clin Endocrinol (Oxf) (2006) 64:588-95. doi: 10.1111/j.1365-2265.2006.02513.x

55. Schilbach K, Strasburger CJ, Bidlingmaier M. Biochemical Investigations in Diagnosis and Follow Up of Acromegaly. Pituitary (2017) 20:33-45. doi: 10.1007/s11102-017-0792-z

56. Mavromati M, Kuhn E, Agostini H, Brailly-Tabard S, Massart C, Piketty ML, et al. Classification of Patients With GH Disorders May Vary According to the IGF-I Assay. J Clin Endocrinol Metab (2017) 102:2844-52. doi: 10.1210/ jc.2017-00202

57. Belaya ZE, Golounina OO, Rozhinskaya LY, Melnichenko GA, Isakov MA, Lutsenko AS, et al. [Epidemiology, Clinical Manifestations and Efficiency of Different Methods of Treatment of Acromegaly According to the United Russian Registry of Patients With Pituitary Tumors]. Probl Endokrinol (Mosk) (2020) 66:93-103. doi: 10.14341/probl10333

58. Niculescu DA, Baciu IF, Capatina C, Galoiu SA, Gheorghiu ML, Radian S, et al. Acromegaly Treatment in Romania. How Close are We to Disease Control? Endokrynol Pol (2017) 68:519-23. doi: 10.5603/EP.a2017.0041

59. Masri-Iraqi H, Akirov A, Shimon I. Medical Treatment Landscape for Active Acromegaly in a Pituitary Center in Israel. Endocr Pract (2020) 26: 1298-303. doi: 10.4158/EP-2020-0171

60. van der Lely AJ, Gomez R, Pleil A, Badia X, Brue T, Buchfelder M, et al. Development of ACRODAT $\left({ }^{\circledR}\right)$, a New Software Medical Device to Assess
Disease Activity in Patients With Acromegaly. Pituitary (2017) 20:692-701. doi: 10.1007/s11102-017-0835-5

61. Giustina A, Bevan JS, Bronstein MD, Casanueva FF, Chanson P, Petersenn S, et al. SAGIT ${ }^{\circledR}$ : Clinician-Reported Outcome Instrument for Managing Acromegaly in Clinical Practice-Development and Results From A Pilot Study. Pituitary (2016) 19:39-49. doi: 10.1007/s11102-015-0681-2

62. Giustina A, Bronstein MD, Chanson P, Petersenn S, Casanueva FF, Sert C, et al. Staging and Managing Patients With Acromegaly in Clinical Practice: Baseline Data From the SAGIT ${ }^{\circledR}$ Validation Study. Pituitary (2019) 22:47687. doi: 10.1007/s11102-019-00977-5

63. Fleseriu M, Fogelfeld L, Gordon MB, Sisco J, Colwell HH, Ludlam WH, et al. Development of a Novel Patient-Reported Measure for Acromegaly: The Acro-TSQ. Pituitary (2019) 22:581-93. doi: 10.1007/s11102-019-00986-4

Conflict of Interest: The authors declare competing interests as follows: MB reports personal fees and non-financial support from Novartis; grants, personal fees and non-financial support from Ipsen; personal fees, non-financial support and other from Pfizer; and personal fees from Recordati outside the submitted work. MD reports personal fees from Pfizer and personal fees from Novartis outside the submitted work. MG reports personal fees from Pfizer and personal fees from Novartis outside the submitted work. VH reports personal fees and nonfinancial support from Pfizer and Ipsen outside the submitted work. II reports lectures' fees from Pfizer and Ipsen outside the submitted work.

DK reports personal fees from Pfizer outside the submitted work. TK reports personal fees from Pfizer and personal fees from Novartis outside the submitted work. MK reports personal fees from Pfizer outside the submitted work. CP reports personal fees from Pfizer, Novartis and Ipsen outside the submitted work. SV reports personal fees from Pfizer outside the submitted work. RG reports employment with Pfizer. SP reports employment with Pfizer. DS reports employment with Pfizer. IS reports personal fees and other from Pfizer; personal fees and other from Medison Pharma; and grants, personal fees and other from Novartis outside the submitted work.

The remaining authors declare that the research was conducted in the absence of any commercial or financial relationships that could be construed as a potential conflict of interest.

This project received funding from Pfizer. The funder had the following involvement with the study: supported the face-to-face advisory board meeting and funded medical writing and editorial assistance.

Publisher's Note: All claims expressed in this article are solely those of the authors and do not necessarily represent those of their affiliated organizations, or those of the publisher, the editors and the reviewers. Any product that may be evaluated in this article, or claim that may be made by its manufacturer, is not guaranteed or endorsed by the publisher.

Copyright (๑ 2022 Bolanowski, Adnan, Doknic, Guk, Hána, Ilovayskaya, Kastelan, Kocjan, Kužma, Nurbekova, Poiana, Szücs, Vandeva, Gomez, Paidac, Simoneau and Shimon. This is an open-access article distributed under the terms of the Creative Commons Attribution License (CC BY). The use, distribution or reproduction in other forums is permitted, provided the original author(s) and the copyright owner(s) are credited and that the original publication in this journal is cited, in accordance with accepted academic practice. No use, distribution or reproduction is permitted which does not comply with these terms. 